\title{
Heavy Metal (Pb) and Its Bioaccumulation in Red Algae (Gracilaria sp.) At Kupang Village, Jabon Sub-District, Sidoarjo District
}

\author{
Yatris Rambu Tega ${ }^{1 *}$, Endang Yuli Herawati ${ }^{1}$, Yuni Kilawati ${ }^{2}$ \\ ${ }^{1}$ Master Program of Aquaculture, Faculty of Fisheries and Marine Sciences, University of Brawijaya, Malang, Indonesia \\ ${ }^{2}$ Department of Aquaculture, Faculty of Fisheries and Marine Sciences, University of Brawijaya, Malang, Indonesia
}

\begin{abstract}
Seaweeds have an inherent capacity to absorb heavy metals from marine water. This intrinsic ability allows these organisms to accumulate much amount of heavy metals over time. This study conducted at Kupang Village, Jabon SubDistrict, Sidoarjo District, where almost $40 \%$ of the area consists of Gracilaria sp. ponds cultured. The purpose of this study was to analyze the $\mathrm{Pb}$ heavy metals concentration in water culture and its concentration in holdfast and thallus of Gracilaria sp. In this research, determination of samples in each pond was taken on day 0 (before planting), 20 days (Initial Production) and on day 40th (Post/Harvest). The aquatic parameters include salinity, temperature, acidity (pH), and dissolved oxygen (DO). Quantitative determination of heavy metals on sample using Atomic Absorption Spectrophotometry (AAS). Determinations of heavy metal accumulation in organism using Bioconcentratin factor (BCF) and Translocation factor was used to calculate the $\mathrm{Pb}$ heavy metal translocation process from the base to the tip of Gracilaria sp. The results of the study showed the highest $\mathrm{Pb}$ concentration found in the second sampling age 20 days, in pond 1 with $7.61 \pm 0.18 \mathrm{mg} \cdot \mathrm{kg}^{-1}$, and pond 2 was $5.35 \pm 0.09 \mathrm{mg} \cdot \mathrm{kg}^{-1}$. This concentration has not exceeded the threshold value that might have an effect if more than $8.6 \mathrm{mg} \cdot \mathrm{kg}^{-1}$. The highest $\mathrm{Pb}$ level at the holdfast of Gracilaria sp. found at age 0 days before planting, which is $3.38 \pm 0.23 \mathrm{mg} \mathrm{kg}^{-1}$ and decreases to post-harvest (age of 40 days) which is $0.84 \pm 0.00 \mathrm{mg} \cdot \mathrm{kg}^{-1}$. The Transaction Factor (TF) of Pb heavy metal value from holdfast to thallus is 1,015 thus Gracilaria sp. absorbs heavy metals in high concentrations at the beginning of planting and is able to release it again before harvest time.
\end{abstract}

Keywords: Bioaccumulation, Gracillaria sp., Heavy Metal, Histological, Red Algae.

\section{INTRODUCTION}

Red seaweed Gracilaria changi is a good potential source of $\beta$-carotene due to the established high content of $5.2 \mathrm{mg} \cdot 100 \mathrm{~g}^{-1}$, which is in comparison with $6.8 \mathrm{mg}^{1} 100 \mathrm{~g}^{-1}$ in carrots [1]. Meanwhile, Kappaphycus alvarezii is commercially important of red algae as a phycocolloid that is extensively applied as a thickening and stabilizing agent in food, pharmaceutical, and cosmetic industries and needed for its cell wall polysaccharide. Also, it has been used in health beverages and anticancer nutraceutical because of its antioxidant content and other nutritive compounds [2].

Heavy metals are significant environmental pollutants and their toxicity is a problem of increasing significance for ecological, evolutionary, nutritional and environmental reasons $[3,4]$. The most commonly found heavy metals in water include arsenic, cadmium, chromium, copper, lead, nickel, and zinc, all of

Correspondence Address:

Yatris Rambu Tega

Email : yatrisrmtg@gmail.com

Address : Faculty of Fisheries and Marine Science, University of Brawijaya, Veteran Malang, 65145. which cause risks for human health if consumed usually through food [5].

Kupang Village is one of the villages located in Jabon Sub-District, Sidoarjo District, where almost $40 \%$ of the area consists of ponds. One of the leading cultivation in the village is Gracilaria sp. seaweed. The presence of airflow from the Porong River is known to contain heavy metals into the aquaculture environment of Gracilaria sp. The previous study stated that the increased lead $(\mathrm{Pb})$ over the threshold in the Porong River is quite dangerous for biota [6]. Also, the results of heavy metal measurements carried out at the Porong river estuary proved that heavy metal lead $(\mathrm{Pb})$ is at the threshold set by the Government with a Pb content of $0.0648 \mathrm{ppm}$ [7].

Seaweeds have an inherent capacity to absorb heavy metals from marine water. This intrinsic ability allows these organisms to accumulate much amount of heavy metals over time. Previous investigations had observed the accumulation of the selected heavy metals in the different species of seaweeds. The study showed that five species of seaweeds have accumulated seven types of heavy metals $(\mathrm{Cd}, \mathrm{Cu}, \mathrm{Mn}, \mathrm{Ni}, \mathrm{Pb}$, $\mathrm{Zi}$, and $\mathrm{Hg}$ ) at varying concentrations [8]. 
The absorption (accumulation) process also influenced by the form of the thallus, e.g. at the base and branching of Gracilaria sp. Naturally, the thallus that located at the base part which attached itself to the substrate has different absorption process from the tip thallus Gracilaria sp. [9]. The purpose of this study was to analyze the accumulator potential of Gracilaria sp through determinations of the concentration and effect of $\mathrm{Pb}$ heavy metals on the holdfast and thallus of the talus seaweed tissue.

\section{MATERIAL AND METHOD}

This research was conducted in JulySeptember 2018, where sampling was carried out in Kupang Village, JabonSub-district, Sidoarjo. Sampling of Gracilaria sp. seaweed conducted in 2 (two) ponds. From each pond, the best quality seaweed was taken as much as $1 \mathrm{~kg}$. Determination of samples in each pond was taken on day 0 (before planting), 20 days (Initial Production) and on day $40^{\text {th }}$ (Post/Harvest).

\section{Aquatic Parameter}

Aquatic parameters observed directly on Gracilaria sp. ponds. The aquatic parameters include salinity, temperature, acidity $(\mathrm{pH})$, and dissolved oxygen (DO) [10].

\section{Atomic Absorption Spectrophotometry (AAS)}

Atomic Absorption Spectrophotometry (AAS)

is an analytical technique that measures the concentration of elements contained in the Gracilaria sp sample. It is the basis for the quantitative determination of metals by using Atomic Absorption Spectrophotometry [11,12].

\section{Data Analysis}

Data obtained from the results of the study were analyzed descriptively quantitatively. AAS was used to determine the content of heavy metal lead $(\mathrm{Pb})$ and Bioconcentratin factor (BCF) to calculate the value of heavy metal accumulation in organisms with the formula:

$$
B C F=\frac{C_{\text {org }}}{C_{\text {water }}}
$$

Description:

BCF = Bioconcentratin factor,

$\mathrm{C}_{\text {organisme }}=$ metal content in organisms $\left(\mathrm{mg} \cdot \mathrm{kg}^{-1}\right)$

$\mathrm{C}_{\text {water }}=$ metal content in water $\left(\mathrm{mg}^{\mathrm{kg}} \mathrm{kg}^{-1}\right)$.

Category of BCF values [11]:

$>1000=$ high accumulative properties category

100-1000 = medium accumulative properties

$<100=$ low accumulative properties

Translocation factor was used to calculate the $\mathrm{Pb}$ heavy metal translocation process from the base to the tip of Gracilaria sp. [12], by the formula:

$$
T F=\frac{B C F_{\text {thallus }}}{B C F_{\text {holdfast }}}
$$

Categories:

TF $>1$ = Phytoextraction mechanism

$\mathrm{TF}<1$ = Phytostabilization mechanism

\section{RESULT AND DISCUSSION}

\section{Aquatic parameter}

The parameters of the water sample which measurements are made directly in the field can be seen in Table 1 . The results of salinity measurements at the research station exceeded the SNI 7904: 2013 threshold of 15-30\% [13]. One of the factors that cause salinity levels increases because the sampling conducted in the dry season (July-August), so that the salt content increases due to evaporation. However, Gracillaria sp. has the ability to tolerate high salinity levels [14].

Table 1. Water Quality in Gracilaria sp. Sampling Water

\begin{tabular}{lcccccc}
\hline \multirow{3}{*}{ Parameter } & \multicolumn{5}{c}{ Gracilaria sp. production age } \\
\cline { 2 - 7 } & \multicolumn{3}{c}{ Pond 1 (Days) } & \multicolumn{3}{c}{ Pond 2 (Days) } \\
\cline { 2 - 7 } & $\mathbf{0}$ & $\mathbf{2 0}$ & $\mathbf{4 0}$ & $\mathbf{0}$ & $\mathbf{2 0}$ & $\mathbf{4 0}$ \\
\hline Salinity (\%o) & 33 & 35 & 41 & 33 & 36 & 35 \\
\hline Temperature $\left({ }^{\circ} \mathrm{C}\right)$ & 27 & 25 & 25 & 27 & 24 & 25 \\
\hline $\mathrm{pH}$ & 7.5 & 6.8 & 6.9 & 7.5 & 7.3 & 7.0 \\
\hline $\mathrm{DO}\left(\mathrm{mg}_{\mathrm{L}} \mathrm{L}^{-1}\right)$ & 5 & 8 & 8 & 8 & 11 & 5 \\
\hline
\end{tabular}

The results of temperature measurements on pond 1 and pond 2 of Gracilaria sp. in Kupang Village, is still in the range of SNI 7904; 2013 [13], i.e. $20-28^{\circ} \mathrm{C}$; which is still considered good for the growth of Gracilaria sp. Thus, it can improve the process of nutrients absorption and accelerate the growth rate of seaweed.

Measurement of the degree of acidity $(\mathrm{pH})$ in the Gracilaria sp. pond range for Pond 1 is 6.8-7.5 and in Pond 2 is 7.0-7.5. The $\mathrm{pH}$ range on Pond 1 and Pond 2 is still in the range of SNI 7578: 2010 [15], namely 6.8-8.2. Waters with a $\mathrm{pH}$ value $=7$ are neutral, $\mathrm{pH}<7$ is said to be an acidic water condition [16]. Decreasing $\mathrm{pH}$ in Pond 1 which less than 7 and said to be acidic will cause greater heavy metal toxicity. The decrease in $\mathrm{pH}$ in the waters can also cause greater levels of pollutant bioaccumulation in organisms [17].

Dissolved oxygen content in the study location both on Pond 1 and Pond 2 has not exceeded the threshold determined by SNI 7578: 2010 [15] which is $>3.0 \mathrm{mg} \cdot \mathrm{L}^{-1}$. The DO content which is always above $3.0 \mathrm{mg} \cdot \mathrm{L}^{-1}$, can be due to research conducted in the morning before noon 
where photosynthesis takes place at that time. It causes the addition of oxygen through photosynthetic processes and the exchange of gas between water and air which causes relative dissolved oxygen levels higher [18,19].

\section{$\mathrm{Pb}$ Metal Content}

In Water

The $\mathrm{Pb}$ concentration analysis on Gracilaria sp. water sampling using the AAS method showed in Figure 1. In the first, second, and third water samples, the highest concentration of $\mathrm{Pb}$ found in water sampling before planting on Pond 1 and Pond 2, and then there was a decrease in the second and third sampling. Pb heavy metals in the waters were found in dissolved and suspended form. Lead solubility in water was quite low, so the levels were relatively small [20]. Furthermore, there was a decrease in ponds aged 40 days, which were below the threshold value of $0.09 \mathrm{mg} . \mathrm{L}^{-1}$, allegedly exchanging lead into sediments through binding to organic matter [21].

\section{In the Sediments}

The level of heavy metals $\mathrm{Pb}$ in the sediment of ponds with Gracilaria sp. using AAS, seen in Figure 2. The highest $\mathrm{Pb}$ content found in the second sampling, age 20 days in pond 1 was 7.61 $\pm 0.18 \mathrm{mg} \cdot \mathrm{kg}^{-1}$ and in the second pond was $5.35 \pm$ $0.09 \mathrm{mg} . \mathrm{kg}^{-1}$. This concentration may be caused by human activity around this area. Various sources of heavy metals include soil erosion, natural weathering of the earth's crust, mining, industrial effluents, urban runoff, sewage discharge, insect or disease control agents applied to crops, and many others [22]. This concentration has not exceeded the threshold value that might have an effect of more than 8.6 mg. $\mathrm{kg}^{-1}$ [23]. It means that the concentration of $\mathrm{Pb}$ is not too dangerous for living things.

In Holdfast of Gracilaria sp.

Measurement of $\mathrm{Pb}$ content in the holdfast of Gracilaria sp. in Kupang Village, using AAS method, can be seen in Figure 3. The highest $\mathrm{Pb}$ level in the holdfast of Gracilaria sp. found at age 0 days before planting, $3.38 \pm 0.23 \mathrm{mg} . \mathrm{L}^{-1}$, and then it decreased to post-harvest age of 40 days which is $0.84 \pm 0.00 \mathrm{mg} . \mathrm{L}^{-1}$.

Gracilaria sp. before planting is the seedlings that originated from the same aquaculture pond in the form of cuttings selected from fresh plants [24], thus experiencing stress [25] and experiencing heavy $\mathrm{Pb}$ heavy metal absorption. $\mathrm{Pb}$ Content in Pond 1 at 20 days decreased more than Pond 2. It is due to in the times of adaptation and at the age of 20 days, the $\mathrm{Pb}$ absorption process in Gracilaria sp. was very strong. The nutrients for breeding and $\mathrm{Pb}$ will also be absorbed.

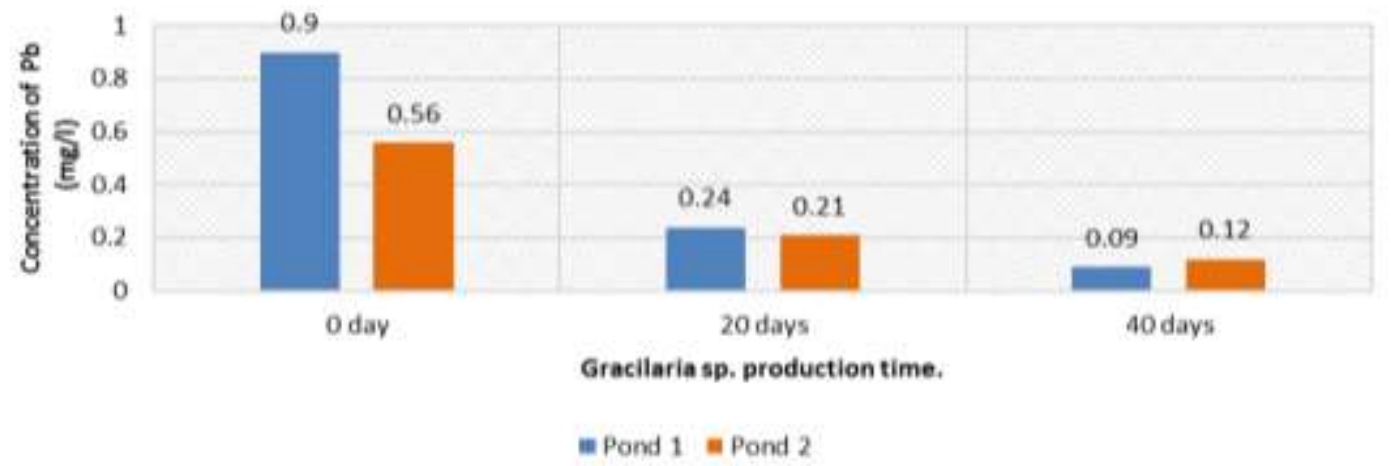

Figure 1. $\mathrm{Pb}$ Concentration in Water

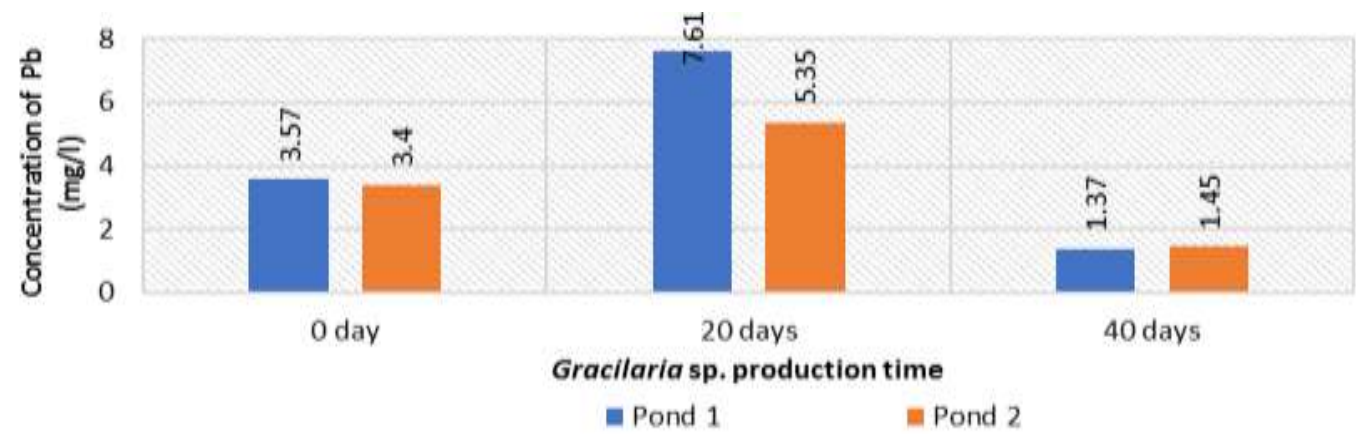

Figure 2. $\mathrm{Pb}$ Concentration in Sediment 


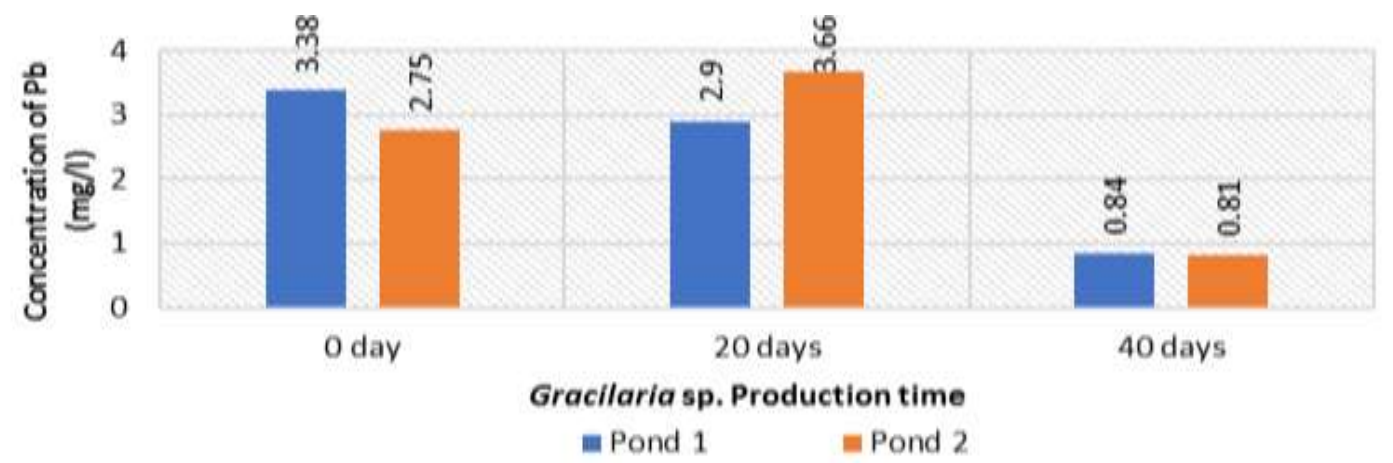

Figure 3. Pb Concentration in holdfast of Gracilaria sp.

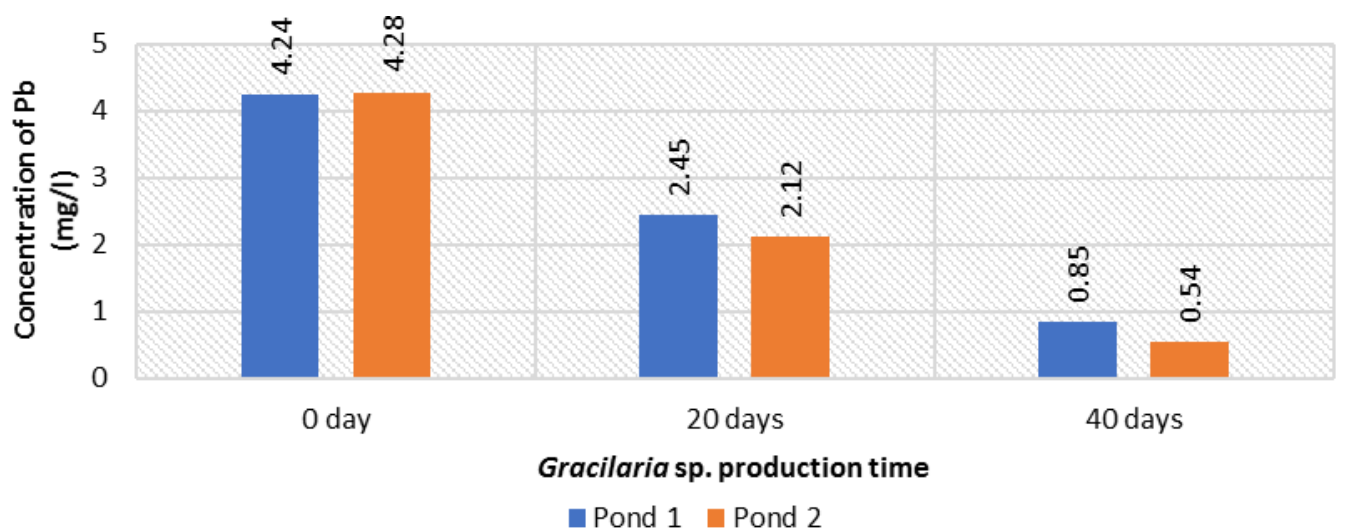

Figure 4. $\mathrm{Pb}$ Concentration in the Young Thallus of Gracilaria sp.

The high adaptation ability of Gracilaria sp. to change the water quality makes it able to survive in the stress of heavy metals without disrupting the growth rate. The growth rate of Gracilaria sp. at the end of the cell meristem is higher than the base. It is because, at the end of the cell, the branching is large, small and still young, while at the base consists of cells that are old with a larger but smaller number of branches [26].

The results of the analysis using AAS at the young thallus of Gracilaria sp. showed high $\mathrm{Pb}$ levels at the first sampling at the age of 0 days for $4.24 \mathrm{mg} . \mathrm{L}^{-1}$. It then decreased at the age of 20 days to $2.12 \mathrm{mg} . \mathrm{L}^{-1}$ and age 40 days to $0.54 \mathrm{mg} . \mathrm{L}^{-1}$ (Fig. 4).

The process of $\mathrm{Pb}$ absorption by Gracilaria sp. influenced by the shape of the thallus. The shape of the Gracilaria thallus is cylindrical and forms clumps with irregular branching types. Otherwise, it does not shape like that at the base, because it has old tissue properties, thus it does not have the activity to multiply itself [27]. Material that has smaller size in diameter has a higher absorption rate than a larger diameter adsorbent [28].
From the results of observations and measurements of $\mathrm{Pb}$ heavy metal concentrations at the holdfast and thallus of Gracilaria sp., it can be used as a bioaccumulator; as well as histology at the holdfast and thallus of Gracilaria sp. can also be used as an accumulator. Parts of seaweed in general consist of the holdfast, which is the basic part of seaweed with functions to stick to the substrate, and thallus which is a form of seaweed growth that resembles branching [29].

\section{Bioconcentration factor (BCF) \\ In Water and Sediment}

The bioconcentration of $\mathrm{Pb}$ heavy metals in water and sediment are shown in Table 2. The results of the sediment BCF calculation in the water with Gracilaria sp. treatment age 0 days, 20 days and 40 days included in the category of low accumulation group.

It was also supported by using the t- test analysis, where significance value (t-tailed) is $0.000<0.05$. It indicates a significant difference at the $95 \%$ level of confidence that there is an influence between the concentration of $\mathrm{Pb}$ in water and sediment on the growth of Gracilaria sp. [30]. 
Table 2. Concentration of $\mathrm{Pb}$ in Water and Sediment

\begin{tabular}{lccc}
\hline \multirow{2}{*}{ Sample } & \multicolumn{3}{c}{ Heavy metal concentration $(\mathrm{Pb})$ and BCF value } \\
\cline { 2 - 4 } & C Water & C Sediment & BCF Value \\
\hline $\mathrm{P} 1_{0}$ & 0.90 & 3.57 & 3.967 \\
$\mathrm{P} 2_{0}$ & 0.56 & 3.40 & 6.071 \\
$\mathrm{P} 1_{20}$ & 0.24 & 7.61 & 31.708 \\
$\mathrm{P} 2_{20}$ & 0.21 & 5.35 & 25.476 \\
$\mathrm{P} 1_{40}$ & 0.09 & 1.37 & 15.222 \\
$\mathrm{P} 2_{40}$ & 0.12 & 1.45 & 12.083 \\
\hline
\end{tabular}

Description:

$\mathrm{P} 1_{0}=$ Pond 1 first sampling (age 0 days)

$\mathrm{P} 2_{0}=$ Pond 2 first sampling (age 0 days)

$\mathrm{P} 1_{20}=$ Pond 1 second sampling (aged 20 days)

$\mathrm{P} 2_{20}=$ Pond 2 second sampling (aged 20 days)

$\mathrm{P} 1_{40}=$ Pond 1 third sampling (aged 40 days)

$\mathrm{P} 2_{40}=$ Pond 2 third sampling (aged 40 days)

Low concentration of $\mathrm{Pb}$ heavy metal in the water because of $\mathrm{Pb}$ is mostly found in the sediment, thus indicating that most of the $\mathrm{Pb}$ compounds in Pond 1 and Pond 2 are in the form of particles or deposits. Anthropogenic materials such as $\mathrm{Pb}$ heavy metals carried by the air from factories and population activities will settle on sediments [31].

In Water and Holdfast of Gracilaria sp.

Bioconcentration factor of $\mathrm{Pb}$ on the seaweed showed in Table 3 . The first sampling has a low $\mathrm{Pb}$ BCF because this sampling was carried out where Gracilaria sp. has not spread on the pond. Accumulatively, the $\mathrm{Pb} \mathrm{BCF}$ value is still low, supported by using the $t$ - test, where significance value ( $t$-tailed) is $0.000<0.05$. The results prove that the $\mathrm{Pb}$ heavy metal concentration varies significantly with the absorption of $\mathrm{Pb}$ heavy metal in the base of water [31].

Table 3. Heavy Metal Concentration $(\mathrm{Pb})$ in Water and Holdfast of Gracilaria sp.

\begin{tabular}{lccc}
\hline \multirow{2}{*}{ Sample } & \multicolumn{3}{c}{ Pb concentration and BCF value } \\
\cline { 2 - 4 } & Water & Holdfast & BCF Value \\
\hline $\mathrm{P} 1_{0}$ & 0.90 & 3.38 & 3.756 \\
$\mathrm{P} 2_{0}$ & 0.56 & 2.75 & 4.911 \\
$\mathrm{P} 1_{20}$ & 0.24 & 2.90 & 12.083 \\
$\mathrm{P} 2_{20}$ & 0.21 & 3.66 & 17.429 \\
$\mathrm{P} 1_{40}$ & 0.09 & 0.84 & 9.333 \\
$\mathrm{P} 2_{40}$ & 0.12 & 0.81 & 6.750 \\
\hline
\end{tabular}

Description:

$\mathrm{P} 1_{0}=$ Pond 1 first sampling (age 0 days)

$\mathrm{P} 2_{0}=$ Pond 2 first sampling (age 0 days)

$\mathrm{P} 1_{20}=$ Pond 1 second sampling (aged 20 days)

$\mathrm{P} 2_{20}=$ Pond 2 second sampling (aged 20 days)

$\mathrm{P} 1_{40}=$ Pond 1 third sampling (aged 40 days)

$\mathrm{P} 2_{40}=$ Pond 2 third sampling (aged 40 days)

In Water and Young Thallus of Gracilaria sp.

$\mathrm{Pb} \mathrm{BCF}$ value at the young thallus of Gracilaria sp. showed in Table 4. Pb BCF value in water and the young thallus of Gracilaria $\mathrm{sp}$. ranges from 4.5-10.208 (Table 4). By using the ttest, where significance value (t-tailed) is $0.000<$ 0.05 , so the hypothesis is proven that there is a difference absorption process in the tip of Gracilaria sp. for $\mathrm{Pb}$ heavy metals. The age of seaweed also greatly affects the process of $\mathrm{Pb}$ heavy metals sequestration in Gracilaria sp. [32].

Table 4. Heavy Metal Concentration $(\mathrm{Pb})$ in Water and Young Thallus of Gracilaria sp.

\begin{tabular}{lccc}
\hline \multirow{2}{*}{ Sample } & \multicolumn{3}{c}{ Pb concentration and BCF value } \\
\cline { 2 - 4 } & Water & Young Thallus & BCF value \\
\hline $\mathrm{P} 1_{0}$ & 0.90 & 4.24 & 4.711 \\
$\mathrm{P} 2_{0}$ & 0.56 & 4.28 & 7.643 \\
$\mathrm{P} 1_{20}$ & 0.24 & 2.45 & 10.208 \\
$\mathrm{P} 2_{20}$ & 0.21 & 2.12 & 10.095 \\
$\mathrm{P} 1_{40}$ & 0.09 & 0.85 & 9.444 \\
$\mathrm{P} 2_{40}$ & 0.12 & 0.54 & 4.500 \\
\hline
\end{tabular}

Description:

$\mathrm{P} 1_{0}=$ Pond 1 first sampling (age 0 days)

$\mathrm{P} 2_{0}=$ Pond 2 first sampling (age 0 days)

$P 1_{20}=$ Pond 1 second sampling (aged 20 days)

$\mathrm{P} 2_{20}=$ Pond 2 second sampling (aged 20 days)

$\mathrm{P} 1_{40}=$ Pond 1 third sampling (aged 40 days)

$\mathrm{P} 2_{40}=$ Pond 2 third sampling (aged 40 days)

The results of bioconcentration factors indicate that Gracilaria sp. both at the holdfast and thallus can accumulate $\mathrm{Pb}$ heavy metals in the waters. A portion of heavy metals absorbed in water and accumulates in the form of particles and then settles on the surface of the sediment [33]. Metals will be bioaccumulated in living organisms or the body of aquatic biota. The amount of metal that accumulates will continue to increase [34].

\section{Translocation Factors (TF)}

$\mathrm{TF}$ analysis is used to calculate the $\mathrm{Pb}$ heavy metal translocation process from the base (holdfast) to the tip (young thallus) of Gracilaria sp. The value from the calculation of the Transaction Factor (TF), can be seen in Table 5 below.

TF value of $\mathrm{Pb}$ from holdfast to thallus is 1,015 so that Gracilaria sp. can be regarded as a high-value bioaccumulator. It was also checked with analysis to verify the existence of significant by using the $t$ - test, where significance value ( $t$ tailed) is $0.000<0.05$. There are several factors that affect the difference in growth in holdfast and thallus Gracilaria sp. one of them is existance of heavy metal [33]. The concentration of $\mathrm{Pb}$ heavy metals contained in the holdfast and thallus of seaweed Gracilaria sp. and the absorption process influences the growth of 
Gracilaria sp. Value of TF $>1$ shows that plants are enriched with metals as $\mathrm{Pb}$ heavy metal accumulators [35].

Tabel 5. TF Concentration on Holdfast to the Young Thallus of Gracilaria sp.

\begin{tabular}{lccc}
\hline \multirow{2}{*}{ Sample } & \multicolumn{3}{c}{ Pb concentration and TF value } \\
\cline { 2 - 4 } & $\begin{array}{c}\text { Young } \\
\text { Thallus }\end{array}$ & Holdfast & TF Value \\
\hline $\mathrm{P} 1_{0}$ & 4.24 & 3.38 & 1.000 \\
$\mathrm{P} 2_{0}$ & 4.28 & 2.75 & 2.000 \\
$\mathrm{P} 1_{20}$ & 2.45 & 2.90 & 0.845 \\
$\mathrm{P} 2_{20}$ & 2.12 & 3.66 & 0.579 \\
$\mathrm{P} 1_{40}$ & 0.85 & 0.84 & 1.000 \\
$\mathrm{P} 2_{40}$ & 0.54 & 0.81 & 0.667 \\
\hline \multicolumn{4}{c}{} \\
\hline
\end{tabular}

$\mathrm{P} 1_{0}=$ Pond 1 first sampling (age 0 days)

$\mathrm{P} 2_{0}=$ Pond 2 first sampling (age 0 days)

$P 1_{20}=$ Pond 1 second sampling (aged 20 days)

$\mathrm{P} 2_{20}=$ Pond 2 second sampling (aged 20 days)

$\mathrm{P} 1_{40}=$ Pond 1 third sampling (aged 40 days)

$\mathrm{P} 2_{40}=$ Pond 2 third sampling (aged 40 days)

According to Bioconcentration factor (BCF) and Translocation Factors (TF), most of the investigations on microalgae and macrophytic algae were considered as valuable indicators because of their accumulation capacity [34]. Trace elements like manganese, copper, lead, and zinc are present in very small quantities and are considered as the essential micro-nutrients for proper growth of the plants. It is well known that elements such as $\mathrm{Cu}, \mathrm{Mo}, \mathrm{Ni}, \mathrm{Cl}$, and $\mathrm{Zn}$ are essential for plant growth in low concentrations [36]. Nevertheless, beyond certain threshold concentrations, these same elements become toxic for most plant species $[37,38]$.

Several plant species are capable of tolerating high concentrations of heavy metals and thus opened new possibilities to use these plants to remediate contaminated soils (phytoremediation). Many studies have been conducted to determine the toxic levels of heavy metals for certain plants, especially those metals considered as public health threats $[36,39]$. At the low concentrations, some of the heavy metals excite some biological processes, but at threshold concentration these become toxic. Being nonbiodegradable, these metals accumulate at various trophic levels through the food chain and can cause human health problems [40].

In humans, these metals hoard in living tissues and thus multiply the danger. Some metals cause physical distress while others may cause life-threatening illness, damage to the vital body system, or cause other damages. Thus, it is very essential to control the emission of heavy metals into the environment. Seaweeds are excellent agents of filtering the metals like zinc, cadmium, copper, nickel and iron and some potential carcinogens from seawater.

\section{CONCLUSION}

Highest $\mathrm{Pb}$ content was found in the second sampling, age 20 days, in Pond 1 for $7.61 \pm 0.18$ $\mathrm{mg} . \mathrm{kg}^{-1}$ and the Pond 2 for $5.35 \pm 0.09 \mathrm{mg} . \mathrm{kg}^{-1}$. This concentration has not exceeded the threshold value that might have an effect of more than $8.6 \mathrm{mg} . \mathrm{kg}^{-1}$. Pb level analysis at the holdfast and thallus of Gracilaria sp. found the highest $\mathrm{Pb}$ content at age 0 days before planting, which is $3.38 \pm 0.23 \mathrm{mg} \cdot \mathrm{kg}^{-1}$ and decreases to post-harvest age of 40 days which is $0.84 \pm 0.00$ mg. $\mathrm{kg}^{-1}$. Transaction Factor (TF) of heavy metal $\mathrm{Pb}$ value from holdfast to thallus is 1.015 . so Gracilaria sp. absorbs heavy metals in high concentrations at the beginning of planting and is able to release it again before harvest time.

\section{REFERENCES}

[1] Phang, S.M., H.Y. Yeong, P.E. Lim, A.R.M. Nor, K.T. Gan. 2010. Commercial varieties of Kappaphycus and Eucheuma in Malaysia. Mal. J. Sci. 29(3). 214-224.

[2] Cornish, M., D. Garbary. 2010. Antioxidants from macroalgae: potential applications in human health and nutrition. Algae. 25. 155171.

[3] Jaishankar, M., B.B. Mathew, M.S. Shah, K.R.S. Gowda. 2014. Biosorption of few heavy metal ions using agricultural wastes. J. Environ. Pollut. Human Health. 2(1). 1-6.

[4] Nagajyoti, P.C., K.D. Lee, T.V.M. Sreekanth. 2010. Heavy metals, occurrence and toxicity for plants: a review. Environ. Chem. Lett. 8(3). 199-216.

[5] Lambert, M., B.A. Leven, R.M. Green. 2000. New methods of cleaning up heavy metal in soils and water; Environmental science and technology briefs for citizens. Kansas State University. Manhattan, KS.

[6] Harlyan, I.K., S.J.H. Syarifah. 2015. Konsentrasi logam berat $\mathrm{Pb}, \mathrm{Cu}$ dan $\mathrm{Zn}$ pada air dan sedimen permukaan ekosistem mangrove di muara Sungai Porong, Sidoarjo, Jawa Timur. Program Study of Fisheries Resources and Marine Sciences. University of Brawijaya. Malang.

[7] Deniz, F., K. Abdulkerim. 2017. Biosorption of heavy metal ions by chemically modified biomass of coastal seaweed community: Studies on phycoremediation system 
modeling and design. Department of Environmental Engineering, Faculty of Engineering and Architecture, Sinop University, 57000 Sinop, Turkey.

[8] Hendrajat, A.E., Suharyanto, M. Markus. 2014. Fluktuasi oksigen terlarut harian pada tambak polikultur udang windu (Penaeus monodon), rumput laut (Gracilaria sp.), dan ikan bandeng (Chanos chanos). Balai Penelitian dan Pengembangan Budidaya Air Payau (Research and Development Center of Brackish Water Cultivation). Maros, South Sulawesi.

[9] Serbula, S.M., T.S. Kalinovic., A.A. Ilic., J.V. Kalinovic, M.M. Steharnik. 2012. Assessment of airborne heavy metal pollution using Pinus spp. and Tilia spp. Aerosol Air Qual. 13. 563-573.

[10] Tonon, A.P., C.O. Mariana, M.S. Eliane, C. Pio. 2011. Absorption of metals and characterization of chemical elements present in three species of Gracilaria (Gracilariaceae) Greville: a genus of economical importance. Rev. Bras. Farmacogn. 21(2). 355-360.

[11] Gosh, M., S.P. Singh. 2005. A Comparative Study of cadmium phyitoextraction by accumulator and weed species. Environ. Pollut. 133. 365-371.

[12] Cui, S., Q. Zhou, L. Chao. 2007. Potential hyperaccumulation of $\mathrm{Pb}, \mathrm{Zn}, \mathrm{Cu}$ and $\mathrm{Cd}$ in endurant plants distributed in an old smeltery, Northeast China. Environ. Geol. 51. 1043-1048.

[13] SNI 7904. 2013. Produksi bibit rumput laut grasilaria (Gracilaria verrucosa) dengan metode sebar di tambak. Badan Standarisasi Nasional (The National Standardization Agency of Indonesia). 293/KEP/BSN/12/ 2013.

[14] Jayasankar, R. 2005. Effect of salinity on physiology of Gracilaria spp. (Gigartinales, Rhodophyta). Seaweed Research and Utilization 27(1\&2) : 19 - 24, 2005.

[15] SNI 7578. 2010. Produksi rumput laut Gracilaria (Gracillaria verrucosa) dengan metode tebar di tambak secara polikultur. Badan Standardisasi Nasional (The National Standardization Agency of Indonesia). 61/KEP/BSN/5/2010.

[16] Sinaga, E.L.R, A. Muhtadi. 2017. Profil suhu, oksigen terlarut dan $\mathrm{pH}$ secara vertikal selama 24 jam di Danau Kelapa Gading
Kabupaten Asahan Sumatera Utara. OmniAkuatika. 12(2). 114-124.

[17] Mukhatasor. 2007. Pencemaran pesisir dan laut. Radyna Paramita Publisher. Jakarta.

[18] Andara, D.R., Haeruddin, A. Suryanto. 2014. Kandungan total padatan tersuspensi, Biocemical Oxygen Demand dan Chemical Oxigen Demand serta indeks pencemaran Sungai Klampisan di Kawasan Industri Candi, Semarang. Manag. Aguat.Resour. 3(3). 177187.

[19] Hsia, C.C.W., A. Schmitz, M. Lambertz, S.F. Perry, J.N. Maina. 2013. Evolution of air breathing: oxygen homeostasis and the transitions from water to land and sky. Compr. Physiol. 3(2). 849-915.

[20] Kumar, R., M. Rani., H. Gupta, B. Gupta. 2014. Trace metal fractionation in water and sediments of an urban river stretch. Chem. Spec. Bioavailab. 26(4). 200-209.

[21] Mushak, P. 2011. Lead in the human environment: fate and transport processes. Trace Metals and other Contaminants in the Environment, Vol. 10. Elsevier.

[22] Morais, S., F.G. Costa, M.L. Pereira. 2012. Heavy metals and human health. In: Oosthuizen, J. (Ed). Environmental Health Emerging Issues and Practice. 227-246.

[23] Febris, G.J., G.F. Werner. 1994. Characterization of toxicants in sedimen from Port Philip Bay. Metal Departement of Conservation and Metal Resourcers Melbourne. Australia.

[24] Julianto, B.S., Badrudin. 2014. Budidaya rumput laut Gracilaria sp. di Tambak, $1^{\text {st }}$ Ed. WWF Indonesia. South Jakarta.

[25] Stengel, D.B., H. McGrath, L.J. Morrison. 2005. Tissue $\mathrm{Cu}, \mathrm{Fe}$ and $\mathrm{Mn}$ concentrations in different-aged and different functional thallus regions of three brown algae from Western Ireland. Estuar. Coast. Shelf Sci. 65. 687-696.

[26] Yong, W.T.L., J.Y.Y. Chin, V.Y. Thien, S. Yasir. 2017. Heavy metal accumulation in feld cultured and tissue cultured Kappaphycus alvarezii and Gracilaria changii. Int. Food Res. J. 24(3). 970-975.

[27] Supriyantini, E., N. Soenardjo, G.W. Santosa, A. Ridlo, S. Sedjati, A. Ambariyanto. 2018. Effectiveness and efficiency of the red seaweed Gracilaria verrucosa as biofilter in $\mathrm{Pb}$ absorption in seawater. AACL Bioflux. 11(3). 887-883. 
[28] Nduka, J.K. 2012. Application of chemically modified and unmodified waste biological sorbents in treatment of wastewater. Int. J. Chem. Eng. Article ID 751240.

[29] Lyer, R., O.D. Clerck, J.J. Bolton, V. Coyne. 2004. Morphological and taxonomic studies of Gracilaria and Gracilariopsis species (Gracilaria les, Rhodophyta) from South Africa. S. Afr. J. Bot. 70(4). 521-539.

[30] Osundiya, M.M., O.O. Ayejuyo, R.A. Olowu., O.A. Bamgboye, A.O. Ogunlola. 2014. Bioaccumulation of heavy metals in fequently consumed leafy vegetable grown along Nigeria-Benin Seme Border, West Africa. Adv. Appl. Sci. 5(1). 1-7.

[31] Palar, H. 1994. Pencemaran dan toksikologi logam berat. Rineka Cipta Publisher. Jakarta.

[32] Sudharsan, S., P. Seedevi, P. Ramasamy, N. Subhapradha, S. Vairamani, A. Shanmugam. 2012. Heavy metal accumulation in seaweeds and sea grasses along Southeast Coast of India. J. Chem. Pharm. 4(9). 42404244.

[33] Dadolahi, S.A., A. Nirkvarz, S.M.B. Nabavi, A. Safahyeh, M.K. Mohseni. 2011. Environmental monitoring of heavy metals in seaweed and associated sediment from the Strait of Hormuz, I.R. Iran. World J.Fish Mar. Sci. 3(6). 576-589.

[34] Serbula, S.M., D.D. Miljkovic, R.M., Kovacevic, Ilic, A.A., 2012. Assessment of air borne heavy metal pollution using plant part sand top soil. Ecotoxicol. Environ. Saf. 76. 209-214.

[35] Rueness, J. 2005. Life history and molecular sequences of Gracilaria vermiculophylla (Gracilaria les, Rhodophyta), a new introduction to European waters. Phycologia. Department of Biology. Blindern, Oslo, Norway.

[36] M Munda, Eutrofication und Truce Metal Cycling in Estuarine and Lagoons. Thessaloniki, Greece, 1993; pp. 45565.

[37] Reeves, R., A.J.M. Baker. 2000. Metalaccumulating plants. Phytoremediation of Toxic Metals: Using Plants to Clean Up the Environment. John Wiley. 193-229.

[38] Blaylock, M.J., J.W. Huang. 2000. Phytoextraction of metals, $1^{\text {st }}$ Ed. John Wiley. 53-70.

[39] Monni, S., M. Salemaa, N. Millar. The tolerance of Empetrum nigrum to copper and nickel. 2000. Env. Pol. 109. 221-229.
[40] Terry, N., G. Banuelos. 2000. Phytoremediation of contaminated soil and water. Lewis Publishers, Inc. Boca Raton. 